\title{
The Intermolecular Interactions of Organic Fluorine Seen in
}

\section{Perspective}

Jason C Cole and Robin Taylor

\section{SUPPORTING INFORMATION}

\section{CONTENTS}

S1. SMARTS definitions of atom types ....................................................................................2

S2. Effect of libration on $-\mathrm{CF}_{3}$ analysis .................................................................................5

S3. F...F geometries .................................................................................................................6

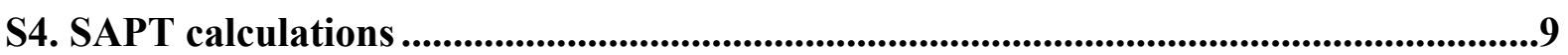

S5. C-F...N_acc geometry distributions.....................................................................................12

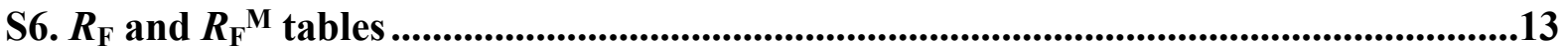

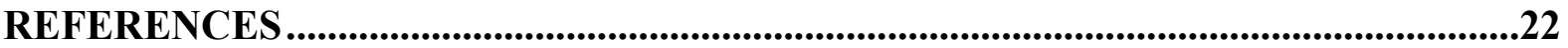




\section{S1. SMARTS definitions of atom types}

Table S1.1.

\begin{tabular}{|c|c|c|}
\hline$S M A R T S^{\mathrm{a}}$ & symbol ${ }^{b}$ & description \\
\hline$[\mathrm{C}, \mathrm{c}][\mathrm{CX} 4](\underline{\mathrm{F}})(\underline{\mathrm{F}}) \underline{\mathrm{F}}$ & $\begin{array}{l}\mathrm{F}_{-} \mathrm{CF}_{3} \mathrm{sh} \\
\mathrm{F}_{-} \mathrm{CF}_{3} \mathrm{md} \\
\mathrm{F}_{-} \mathrm{CF}_{3} \mathrm{lg}\end{array}$ & $\begin{array}{l}\mathrm{C}-\mathrm{CF}_{3} \text { fluorine. There are three atom } \\
\text { types depending on whether the C-F } \\
\text { bond is the shortest (sh), median (md) } \\
\text { or longest ( }(\mathrm{g}) \text { in the group }\end{array}$ \\
\hline $\begin{array}{l}{[\mathrm{C}, \mathrm{c}] \mathrm{c} 1 \mathrm{c}(\underline{\mathrm{F}}) \mathrm{c}(\underline{\mathrm{F}}) \mathrm{c}(\underline{\mathrm{F}}) \mathrm{c}(\underline{\mathrm{F}}) \mathrm{c} 1(\underline{\mathrm{F}})} \\
{[\mathrm{cH} 1] 1 \mathrm{c}(\underline{\mathrm{F}}) \mathrm{c}(\underline{\mathrm{F}}) \mathrm{c}(\underline{\mathrm{F}}) \mathrm{c}(\underline{\mathrm{F}}) \mathrm{c} 1(\underline{\mathrm{F}})}\end{array}$ & $\mathrm{F}_{-} \mathrm{C}_{6} \mathrm{~F}_{5}$ & Pentafluorophenyl fluorine \\
\hline 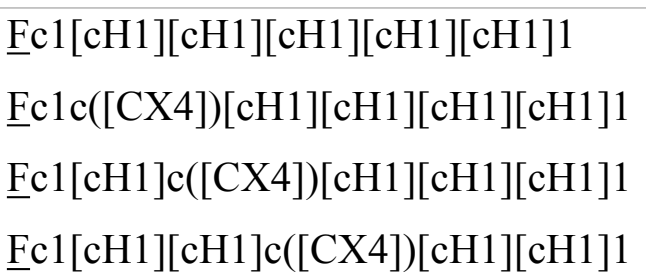 & F_phe & $\begin{array}{l}\text { Fluorine in fluorobenzene or } \\
\text { fluorophenyl }\end{array}$ \\
\hline c $\underline{F}$ & F_aro & $\begin{array}{l}\text { Fluorine on any aromatic carbon other } \\
\text { than those mentioned above }\end{array}$ \\
\hline $\begin{array}{l}{[\mathrm{c}, \mathrm{C}][\mathrm{CH} 2] \underline{\mathrm{F}}} \\
{[\mathrm{c}, \mathrm{C}][\mathrm{CH} 1]([\mathrm{c}, \mathrm{C}]) \underline{\mathrm{F}}} \\
{[\mathrm{c}, \mathrm{C}] \mathrm{C}([\mathrm{c}, \mathrm{C}])([\mathrm{c}, \mathrm{C}]) \underline{\mathrm{F}}}\end{array}$ & F_ali & $\begin{array}{l}\text { Fluorine on } \mathrm{Csp}^{3} \text { that is otherwise } \\
\text { bonded only to } \mathrm{C} \text { or } \mathrm{H}\end{array}$ \\
\hline$[\mathrm{C}, \mathrm{c}] \underline{\mathrm{F}}$ & F_org & Any C-F fluorine \\
\hline$[\mathrm{C}, \mathrm{c}] \underline{\mathrm{H}}$ & H_C & Any $\mathrm{C}-\mathrm{H}$ hydrogen \\
\hline$[\mathrm{N}, \mathrm{n}, \mathrm{O}, \mathrm{o}] \underline{\mathrm{H}}$ & H_X & $\mathrm{N}-\mathrm{H}$ or $\mathrm{O}-\mathrm{H}$ hydrogen \\
\hline $\begin{array}{l}{[\mathrm{NX} 4] \mathrm{C} \underline{\mathrm{H}}} \\
\mathrm{C}=[\mathrm{NX} 3] \mathrm{C} \underline{\mathrm{H}} \\
{[\mathrm{C}, \mathrm{c}][\mathrm{NX} 3]=\mathrm{C} \underline{\mathrm{H}}} \\
{[\mathrm{nX} 3][\mathrm{C}, \mathrm{c}] \underline{\mathrm{H}}}\end{array}$ & H_Cpos & $\mathrm{N}^{+}-\mathrm{C}-\mathrm{H}$ hydrogen \\
\hline $\begin{array}{l}{[\mathrm{N}, \mathrm{n}, \mathrm{O}, \mathrm{F}][\mathrm{CX} 3] \underline{\mathrm{H}}} \\
{[\mathrm{N}, \mathrm{n}, \mathrm{O}, \mathrm{F}] \underline{\mathrm{c}} \underline{\mathrm{H}}}\end{array}$ & H_Cpolar & $\begin{array}{l}\mathrm{C}-\mathrm{H} \text { hydrogen, } \mathrm{C} \text { bonded to electron- } \\
\text { withdrawing atom }(\mathrm{N}, \mathrm{O}, \mathrm{F})\end{array}$ \\
\hline $\mathrm{c} \underline{\mathrm{H}}$ & H_Caro & Hydrogen bonded to aromatic carbon \\
\hline$[\mathrm{CX} 2] \underline{\mathrm{H}}$ & H_Csp & Csp-H hydrogen \\
\hline$[\mathrm{CX} 3] \underline{\mathrm{H}}$ & H_Csp ${ }^{2}$ & $\mathrm{Csp}^{2}-\mathrm{H}$ hydrogen \\
\hline$[\mathrm{CX} 4] \underline{\mathrm{H}}$ & $\mathrm{H} \_\mathrm{Csp}^{3}$ & $\mathrm{Csp}^{3}-\mathrm{H}$ hydrogen \\
\hline $\mathrm{CCl}$ & Cl_ali & Chlorine on aliphatic carbon \\
\hline
\end{tabular}




\begin{tabular}{|c|c|c|}
\hline $\mathrm{c} \underline{\mathrm{Cl}}$ & Cl_aro & Chlorine on aromatic carbon \\
\hline$[\mathrm{C}, \mathrm{c}] \underline{\mathrm{Br}}$ & Br_org & Bromine on any carbon \\
\hline$[\mathrm{C}, \mathrm{c}] \underline{\mathrm{I}}$ & I_org & Iodine on any carbon \\
\hline$[\underline{\mathrm{O}}, \underline{\mathrm{o}}]$ & $\mathrm{O}$ & Any oxygen \\
\hline $\begin{array}{l}{[\underline{\mathrm{NX} 1]}} \\
{[\underline{\mathrm{NX}} 2]} \\
{[\underline{\mathrm{n} X} 2]} \\
{ }^{[\mathrm{NXX} 3]^{\mathrm{c}}}\end{array}$ & N_acc & $\begin{array}{l}\text { Nitrogen with localized lone pair } \\
\text { capable of accepting a hydrogen bond }\end{array}$ \\
\hline [X4] & C_sp ${ }^{3}$ & Tetrahedral carbon \\
\hline$\underline{\mathrm{c}}$ & C_aro & Aromatic carbon \\
\hline 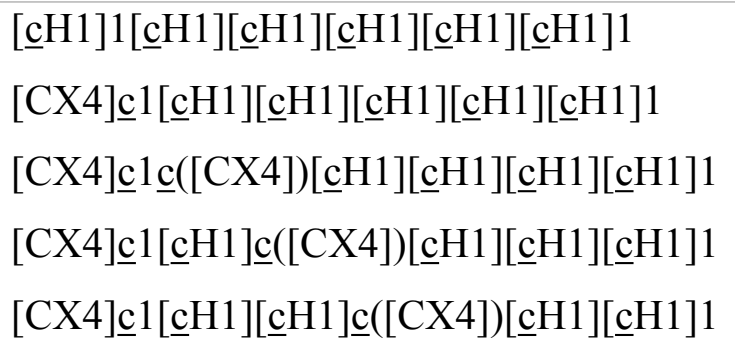 & C_aro_CH & $\begin{array}{l}\text { Carbon in } \mathrm{C}_{6} \mathrm{H}_{6}, \mathrm{C}-\mathrm{C}_{6} \mathrm{H}_{5} \text { or } \mathrm{C}-\mathrm{C}_{6} \mathrm{H}_{4}-\mathrm{C} \\
\text { rings }\end{array}$ \\
\hline$[\mathrm{nX} 2] 1 \underline{\operatorname{ccccc} 1}$ & C_aro_N & Carbon in pyridine ring \\
\hline $\begin{array}{l}{[\mathrm{nX} 2] 1[\mathrm{nX} 2] \underline{\mathrm{cccc} 1}} \\
{[\mathrm{nX} 2] 1 \underline{\mathrm{c}}[\mathrm{nX} 2] \underline{\mathrm{ccc} 1}} \\
{[\mathrm{nX} 2] 1 \underline{\mathrm{cc}}[\mathrm{nX} 2] \underline{\mathrm{cc} 1}}\end{array}$ & C_aro_ $\mathrm{N}_{2}$ & $\begin{array}{l}\text { Carbon in pyridazine, pyrimidine or } \\
\text { pyrazine ring }\end{array}$ \\
\hline $\begin{array}{l}\underline{\mathrm{c}} 1(\mathrm{~F}) \underline{\mathrm{c}}(\mathrm{F}) \underline{\mathrm{c}}(\mathrm{F}) \underline{\mathrm{c}}(\mathrm{F}) \underline{\mathrm{c}}(\mathrm{F}) \underline{\mathrm{c}} 1 \mathrm{~F} \\
\underline{\mathrm{c}} 1 \underline{\mathrm{c}}(\mathrm{F}) \underline{\mathrm{c}}(\mathrm{F}) \underline{\mathrm{c}}(\mathrm{F}) \underline{\mathrm{c}}(\mathrm{F}) \underline{\mathrm{c}} 1 \mathrm{~F} \\
\underline{\mathrm{c}} 1 \underline{\mathrm{c}}(\mathrm{F}) \underline{\mathrm{c}}(\mathrm{F}) \underline{\mathrm{c}}(\mathrm{F}) \underline{\mathrm{c}} 1 \mathrm{~F} \\
\underline{\mathrm{c}} 1 \underline{\mathrm{c}}(\mathrm{F}) \underline{\mathrm{c}}(\mathrm{F}) \underline{\mathrm{c}}(\mathrm{F}) \underline{\mathrm{c}} 1 \mathrm{~F} \\
\underline{\mathrm{c}} 1 \underline{\mathrm{c}}(\mathrm{F}) \underline{\mathrm{c}}(\mathrm{F}) \underline{\mathrm{c}}(\mathrm{F}) \underline{\mathrm{c}} 1 \mathrm{~F}\end{array}$ & C_aro_F & $\begin{array}{l}\text { Carbon in } \mathrm{C}_{6} \mathrm{~F}_{6},-\mathrm{C}_{6} \mathrm{~F}_{5} \text { or }>\mathrm{C}_{6} \mathrm{~F}_{4} \\
\text { moiety }\end{array}$ \\
\hline$[\mathrm{nX} 3] 1 \underline{\mathrm{ccccc} 1}$ & C_aro_N $\mathrm{N}^{+}$ & Carbon in pyridinium ring \\
\hline$[\mathrm{C}, \mathrm{c}][\underline{\mathrm{N} X} 3](=[\mathrm{OX} 1])=[\mathrm{OX} 1]$ & N_nitro & Nitro nitrogen \\
\hline$\underline{\mathrm{C}}=\mathrm{O}$ & C_carbonyl & Carbonyl carbon \\
\hline$[\underline{\mathrm{S} X} 1]$ & S_term & Terminal sulfur \\
\hline $\begin{array}{l}{[\underline{\mathrm{S} X} 2] \mathrm{N}} \\
{[\underline{\mathrm{S} X} 2] \mathrm{C}=\mathrm{N}} \\
{[\underline{\mathrm{S}} \mathrm{X} 2] \mathrm{n}} \\
{[\underline{\mathrm{S}} \mathrm{X} 2] \mathrm{cn}}\end{array}$ & $\mathrm{S} \_\mathrm{R}_{2}$ polar & $\begin{array}{l}\text { 2-coordinate sulfur with nearby } \\
\text { nitrogen atom }\end{array}$ \\
\hline [ㅁX2] & $\mathrm{S}_{-} \mathrm{R}_{2}$ & Other 2-coordinate sulfur \\
\hline
\end{tabular}




\section{[저2]}

a Type is assigned to the underlined atom(s); when a type has $>1$ SMARTS, a match against any is sufficient; when an atom matches several types, the most specific is used.

${ }^{\mathrm{b}}$ Ordered in more or less the same order as they are used in the paper

${ }^{\mathrm{c}}$ Matching against these SMARTS strings only took place after nitrogen atoms that matched the following strings had been eliminated as non-acceptors: [NX3]-A=A, [NX3]-aa, [NX3] $=\mathrm{A},[\underline{\mathrm{n} X} 3]$, $[\mathrm{NX} 2]=[\underline{\mathrm{NX}} 2]=[\mathrm{NX} 1],[\mathrm{NX} 2][\underline{\mathrm{NX}} 2] \#[\mathrm{NX} 1],[\underline{\mathrm{NX}} 2] \#[\mathrm{CX} 1]$ 


\section{S2. Effect of libration on $-\mathrm{CF}_{3}$ analysis}

There is a potential problem with the atom types assigned to $-\mathrm{CF}_{3}$ fluorine atoms.

Trifluoromethyl groups in crystals are notoriously prone to high thermal motion. While disordered structures were rejected from our data set there will inevitably remain many C-F bonds whose measured lengths are shortened by libration. We were concerned that this might lead to misassignments of $\mathrm{F}_{-} \mathrm{CF}_{3} \lg , \mathrm{F}_{-} \mathrm{CF}_{3}$ md and $\mathrm{F}_{-} \mathrm{CF}_{3}$ sh atom types. Fortunately, it is quite likely that all three $\mathrm{C}-\mathrm{F}$ bonds of a $-\mathrm{CF}_{3}$ group will be affected more or less equally by libration, in which case the problem will not be important. This was checked by downloading the anisotropic atomic displacement parameters of all the structures in our data set for which they are available in the CSD. The mean and maximum thermal-ellipsoid semi-axis lengths of atoms assigned as $\mathrm{F}_{-} \mathrm{CF}_{3}$ sh were, on average, higher than those of $\mathrm{F}_{-} \mathrm{CF}_{3} \mathrm{md}$ and $\mathrm{F}_{-} \mathrm{CF}_{3} \lg$ but the differences were small and not statistically significant. When the F...F $R_{\mathrm{F}}$ analysis was performed on $-\mathrm{CF}_{3}$ groups in which no fluorine atom had an ellipsoid semi-axis length exceeding $0.6 \AA$ it gave results that were little different from those in Table 2 of the paper. That was also the case when the analysis was repeated on structures determined at $\leq 165 \mathrm{~K}$. We conclude that libration has a negligible effect on the results in Table 2 of the paper. 


\section{S3. F...F geometries}

Recent studies of F...F geometries have been rather inconclusive. Varadwaj et al. found that $\mathrm{F}$...F distances in a very large sample of $\mathrm{CF}_{3} \ldots \mathrm{F}-\mathrm{C}$ interactions fell in the range $2.9-3.8 \AA$, with C-F...F angles peaking around $100^{\circ}$ and rarely close to $180^{\circ} .{ }^{1}$ Janjić et al. stated that $\mathrm{R}_{1^{-}}$ $F_{1} \ldots F_{2}-R_{2}$ interactions favor trans geometries $\left(R_{1}-F_{1} \ldots F_{2}\right.$ and $F_{1} \ldots F_{2}-R_{2}$ angles both $\left.>90^{\circ}\right)$, cis geometries $\left(\mathrm{R}_{1}-\mathrm{F}_{1} \ldots \mathrm{F}_{2}\right.$ and $\mathrm{F}_{1} \ldots \mathrm{F}_{2}-\mathrm{R}_{2}$ angles both $\left.\leq 90^{\circ}\right)$ and the L-geometry $\left(\mathrm{R}_{1}-\mathrm{F}_{1} \ldots \mathrm{F}_{2}\right.$ $\left.\approx 180^{\circ}, \mathrm{F}_{1} \ldots \mathrm{F}_{2}-\mathrm{R}_{2} \approx 90^{\circ}\right){ }^{2}$ Esterhuysen et al. said that short contacts between $-\mathrm{CF}_{3}$ groups exhibited no strong directional preferences. ${ }^{3}$ We revisited the subject using only primary, LoS F...F interactions. We felt that they were more likely to reveal inherent geometrical preferences than longer and possibly incidental interactions.

Table S3.1 shows the variation of F...F distance with atom type. We had anticipated that $\mathrm{F}_{-} \mathrm{CF}_{3} \mathrm{sh} . . \mathrm{F} \mathrm{CF}_{3}$ sh might form the shortest distances as it is the only F...F interaction with $R_{\mathrm{F}}$ significantly above 1 . Furthermore, $\mathrm{F}_{-} \mathrm{CF}_{3}$ sh is predicted to be polar flattened ${ }^{3}$ which might also reduce F...F distances. Its average distance, 2.929(5) $\AA$, is indeed the shortest of the interactions between trifluoromethyl fluorine atoms, though not by much. However, the four $\mathrm{F} \ldots \mathrm{F}$ interactions not involving $-\mathrm{CF}_{3}$ atoms are all significantly shorter, the longest being 2.887(4) $\AA$ for $\mathrm{F}_{-} \mathrm{C}_{6} \mathrm{~F}_{5} \ldots \mathrm{F}_{-} \mathrm{C}_{6} \mathrm{~F}_{5}$. This remains true if the analysis is confined to lowtemperature $(\leq 165 \mathrm{~K})$ studies, suggesting that the result is not merely an artefact of C-F libration. It appears that interactions between $-\mathrm{CF}_{3}$ fluorine atoms are relatively long compared to other F...F interactions. Perhaps $-\mathrm{CF}_{3}$ groups are often prevented from approaching too closely because the primary F...F contact - even if attractive - is often accompanied by other, mildly repulsive F...F interactions.

Table S3.1. Mean distances of primary, line-of-sight F...F interactions

\begin{tabular}{|c|c|}
\hline interaction & mean $(\mathrm{se})(\AA)$ \\
\hline $\mathrm{F}_{-} \mathrm{CF}_{3} \mathrm{sh} \ldots \mathrm{F} \_\mathrm{CF}_{3} \mathrm{sh}$ & $2.929(5)$ \\
\hline $\mathrm{F}_{-} \mathrm{CF}_{3} \mathrm{md} \ldots \mathrm{F} \mathrm{CF}_{3} \mathrm{sh}$ & $2.974(5)$ \\
\hline $\mathrm{F} \_\mathrm{CF}_{3} \mathrm{md} . . . \mathrm{F} \mathrm{CF}_{3} \mathrm{md}$ & $2.959(7)$ \\
\hline $\mathrm{F}_{-} \mathrm{CF}_{3} \lg \ldots \mathrm{F}_{-} \mathrm{CF}_{3} \mathrm{md}$ & $2.976(4)$ \\
\hline $\mathrm{F}_{-} \mathrm{CF}_{3} \lg \ldots \mathrm{F}_{-} \mathrm{CF}_{3} \mathrm{sh}$ & $2.993(5)$ \\
\hline $\mathrm{F}_{-} \mathrm{CF}_{3} \lg \ldots \mathrm{F}_{-} \mathrm{CF}_{3} \lg$ & $2.951(7)$ \\
\hline $\mathrm{F}_{-} \mathrm{C}_{6} \mathrm{~F}_{5} \ldots \mathrm{F}_{-} \mathrm{C}_{6} \mathrm{~F}_{5}$ & $2.887(4)$ \\
\hline $\mathrm{F}$ _aro...F_aro & $2.876(4)$ \\
\hline
\end{tabular}


F_phe...F_phe

F_ali...F_ali

se $=$ standard error

The reduction in electron density produced in $\mathrm{F}_{-} \mathrm{CF}_{3}$ sh atoms by polarization and, specifically, the anomeric effect are localized in the polar regions. ${ }^{3}$ This suggests that $\mathrm{F}_{-} \mathrm{CF}_{3}$ sh might preferably form $\mathrm{F}$...F interactions along the extension of the C-F bond, making the corresponding C-F ...F angle close to $180^{\circ}$. Figure S3.1a shows the histograms of $\mathrm{C}-\mathrm{F}$...F angles at atoms of type $\mathrm{F}_{-} \mathrm{CF}_{3} \lg$ (blue bars), $\mathrm{F}_{-} \mathrm{CF}_{3}$ md (orange) and $\mathrm{F}_{-} \mathrm{CF}_{3}$ sh (gray). All three distributions peak around $100-120^{\circ}$ but this does not properly reflect the energetic preferences of the interactions because of the "cone effect"4 (the number of positions in space at which an A-B...C angle of $\alpha$ can occur depends on $\sin \alpha$ ). Correction for this produces the distributions in Figure S3.1b. Two things are clear. Firstly, crystal-structure data are consistent with C-F...F having an energetic preference for $180^{\circ}$ or thereabouts. Secondly, the angle at $\mathrm{F}_{-} \mathrm{CF}_{3} \mathrm{sh}$ has a greater preference for values $>150^{\circ}$ than do the angles at $\mathrm{F}_{-} \mathrm{CF}_{3} \lg$ and $\mathrm{F}_{-} \mathrm{CF}_{3} \mathrm{md}$, while the reverse is true for angles $<140^{\circ}$. This is as predicted above but the effect is small, doubtless because the angles are strongly influenced by local crystal packing forces.
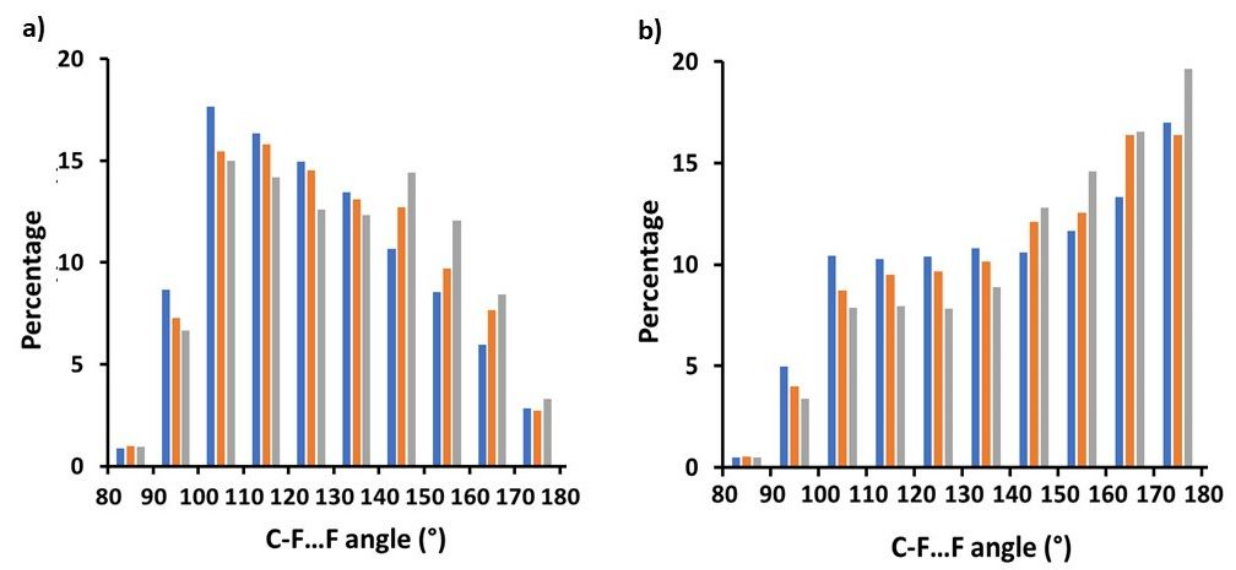

Figure S3.1. Distributions of C-F...F angles in primary, line-of-sight interactions. (a) Raw percentages, (b) percentages corrected for cone effect. Angles at atoms of type $\mathrm{F}_{-} \mathrm{CF}_{3} \lg$ (blue bars), F_ $\mathrm{CF}_{3} \mathrm{md}$ (orange), $\mathrm{F}_{-} \mathrm{CF}_{3}$ sh (gray).

We detected no other patterns in the C-F...F angle data save for a sizable number of interactions (ca 15\%) where the two C-F...F angles are exactly equal. This of course indicates that the two C-F groups are symmetry related. 
Figure S3.2 shows the distribution of the absolute value of the C-F...F-C torsion angle for all primary F...F contacts. The enormous peak in the $170-180^{\circ}$ bin is due in part to F...F interactions across inversion centers, for which the torsion angle is necessarily $180^{\circ}$, although there is still a peak even if these interactions are excluded. While the distribution is reasonably flat from 0 to $170^{\circ}$, we found the very minor discrepancies from uniformity in this range (i.e., the small peaks at about 60 and $120^{\circ}$ ) to be statistically significant (1-sample $\chi^{2}$ test, $\chi^{2}=80.6$ ). The distribution for the subset of contacts between fluorine atoms of $-\mathrm{CF}_{3}$ groups shows the same features except that the minor peak at $120^{\circ}$ is not present.

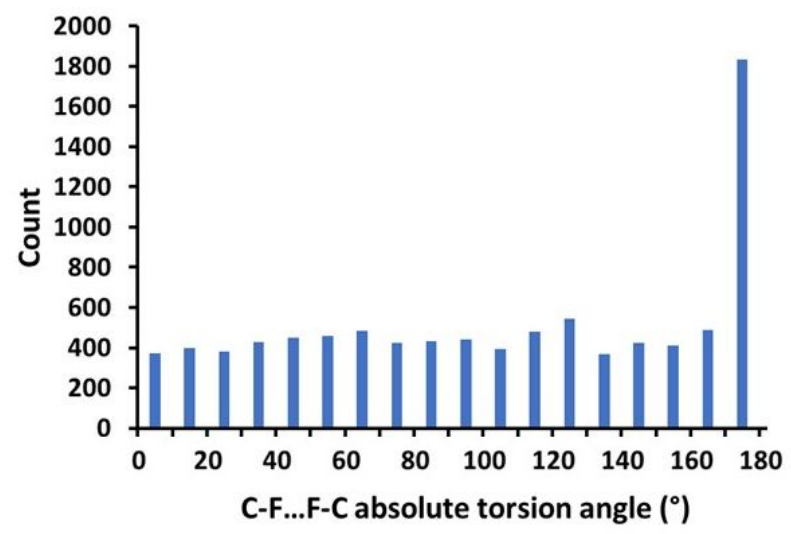

Figure S3.2. Histogram of C-F...F-C torsion angles for primary, line-of-sight F ...F interactions. 


\section{S4. SAPT calculations}

SAPT calculations were performed using the PSI4 package (https://psicode.org/).

S4.1. LAQKEV dimer calculations. The interaction energy of an F ... O linked dimer extracted from CSD refcode LAQKEV was assessed using SAPT0 and F-SAPT0 (a method for fragment partitioning of SAPT0 energies) to evaluate the overall fragment contributions. SAPT0 theory was applied, rather than a preferable higher-order SAPT due to the size of the model system. Thus, we regard the results as illustrative of direction rather than highly quantitative.

Standard SAPT0 as available in the PSI4 package was used for calculations. The jun-ccpVDZ basis set was used in all calculations. F-SAPT0 requires a user definition of partitioning over the dimer. The partitioning used is summarised in Figure S4.1.

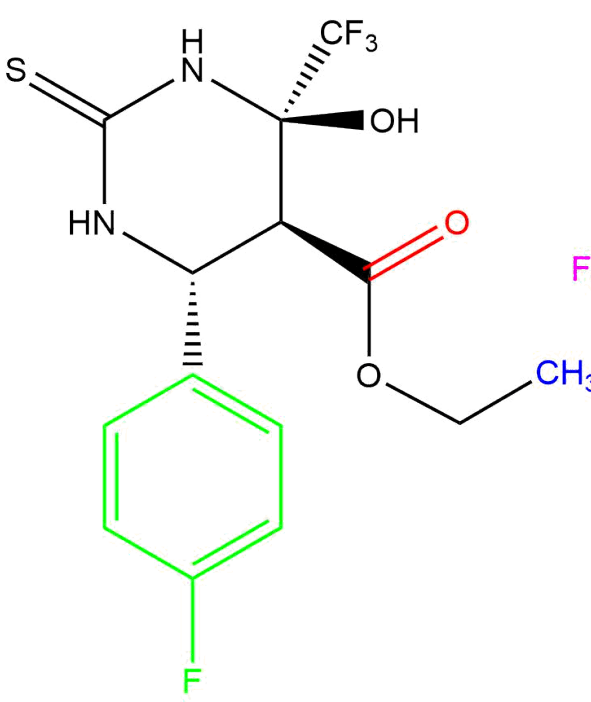

Molecule 1

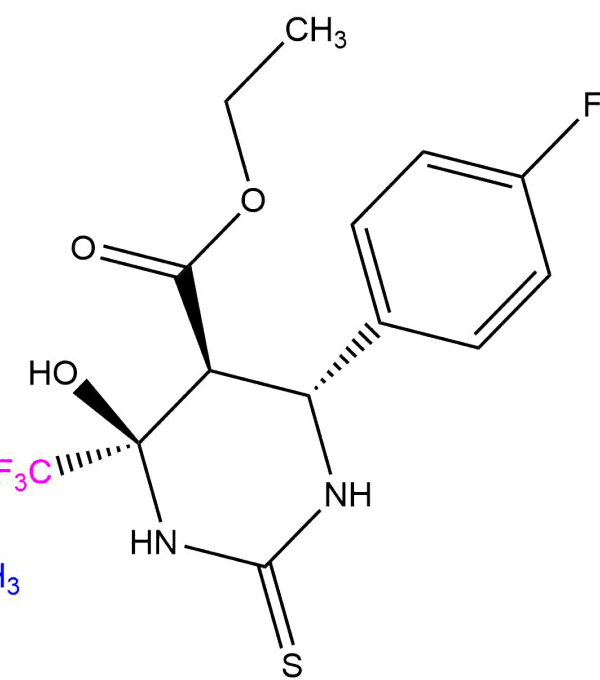

Molecule 2

Figure S4.1. LAQKEV and F-SAPT0 partitioning. Defined F-SAPT fragments in molecule 1 were: fluorophenyl (green) carbonyl (red), methyl (blue), and other (black). In molecule 2 they were: trifluoromethyl (magenta) and other (black).

As Table S4.1 shows, the total contribution of the $\mathrm{CF}_{3}$ group to the dimer energy is relatively small. Seemingly the contributions are balanced between electrostatic repulsion to the carbonyl, and attraction to other components in molecule 2. 
Table S4.1. F-SAPT0 dimer results. All energies are in $\mathrm{kcal} / \mathrm{mol}$. Key partitions are shown in red.

\begin{tabular}{llllllll} 
molecule1 & molecule2 & electrostatic & exchange & $\begin{array}{l}\text { induction } \\
(\mathbf{A}->\mathbf{B})\end{array}$ & $\begin{array}{l}\text { induction } \\
(\mathbf{B}->\mathbf{A})\end{array}$ & dispersion & total \\
\hline CO & $\mathrm{CF}_{3}$ & 2.683 & 0.563 & -0.018 & -0.068 & -0.412 & 2.747 \\
CO & OTHER & -1.93 & 0.003 & 0.012 & 0.054 & -0.091 & -1.953 \\
CH3 & CF3 & 0.08 & 0.44 & -0.013 & 0.017 & -0.408 & 0.116 \\
CH3 & OTHER & -0.049 & 0.002 & 0.006 & 0.032 & -0.13 & -0.139 \\
PHENYL & CF3 & -0.084 & 0.952 & 0.017 & -0.035 & -0.818 & 0.032 \\
PHENYL & OTHER & -1.227 & 0.969 & -0.096 & -0.109 & -1.311 & -1.774 \\
OTHER & CF & -2.746 & 0.025 & -0.009 & -0.046 & -0.281 & -3.057 \\
OTHER & OTHER & 1.567 & 0 & -0.003 & -0.207 & -0.22 & 1.137 \\
CO & All & 0.753 & 0.566 & -0.006 & -0.015 & -0.503 & 0.794 \\
CH3 & All & 0.032 & 0.442 & -0.008 & 0.048 & -0.538 & -0.024 \\
PHENYL & All & -1.311 & 1.921 & -0.079 & -0.144 & -2.129 & -1.741 \\
OTHER & All & -1.178 & 0.026 & -0.012 & -0.253 & -0.502 & -1.92 \\
All & CF 3 & -0.066 & 1.98 & -0.023 & -0.133 & -1.92 & -0.161 \\
All & OTHER & -1.639 & 0.975 & -0.082 & -0.231 & -1.753 & -2.729 \\
All & All & -1.705 & 2.955 & -0.105 & -0.364 & -3.672 & -2.891 \\
\hline
\end{tabular}

S4.2. ABENEB dimer calculations. Calculations were undertaken to investigate a $\mathrm{C}=\mathrm{O} \ldots \mathrm{F}$ interaction in the CSD entry ABENEB. Due to the delocalized nature of the carbonyl-phenyl ring system, we decided to use a fragment-replacement approach to assess the impact of a mediating hydroxyl on the $\mathrm{C}=\mathrm{O} \ldots \mathrm{F}$ contact rather than F-SAPT0. F-SAPT0 involves partitioning energies across fragments. Recommended use of F-SAPT0 dictates that fragments be separated at $\sigma$-bonds to avoid partitioning of energies across delocalised regions of the molecule. For ABENEB, this would have meant breaking the phenyl - carbonyl bond. As the nature of this bond is, in practice, quite delocalised, we felt that F-SAPT0 may not be appropriate for assessing this system.

Instead, we performed calculations at a higher level of theory (SAPT2+ with aug-ccpVDZ: the Silver standard as recommended by Parker et al. ${ }^{5}$ ) for a molecular dimer extracted from ABENEB (Figure S4.2). The dimer was then edited to replace the $\mathrm{OH}$ with a hydrogen in the same geometry and the relative energies of the two systems were compared. As can be 
seen from Table $\mathrm{S} 4.2$, the presence of the $\mathrm{OH}$ group is stabilizing, flipping the overall SAPT2+ energy from attractive in the observed dimer to repulsive in the edited dimer.
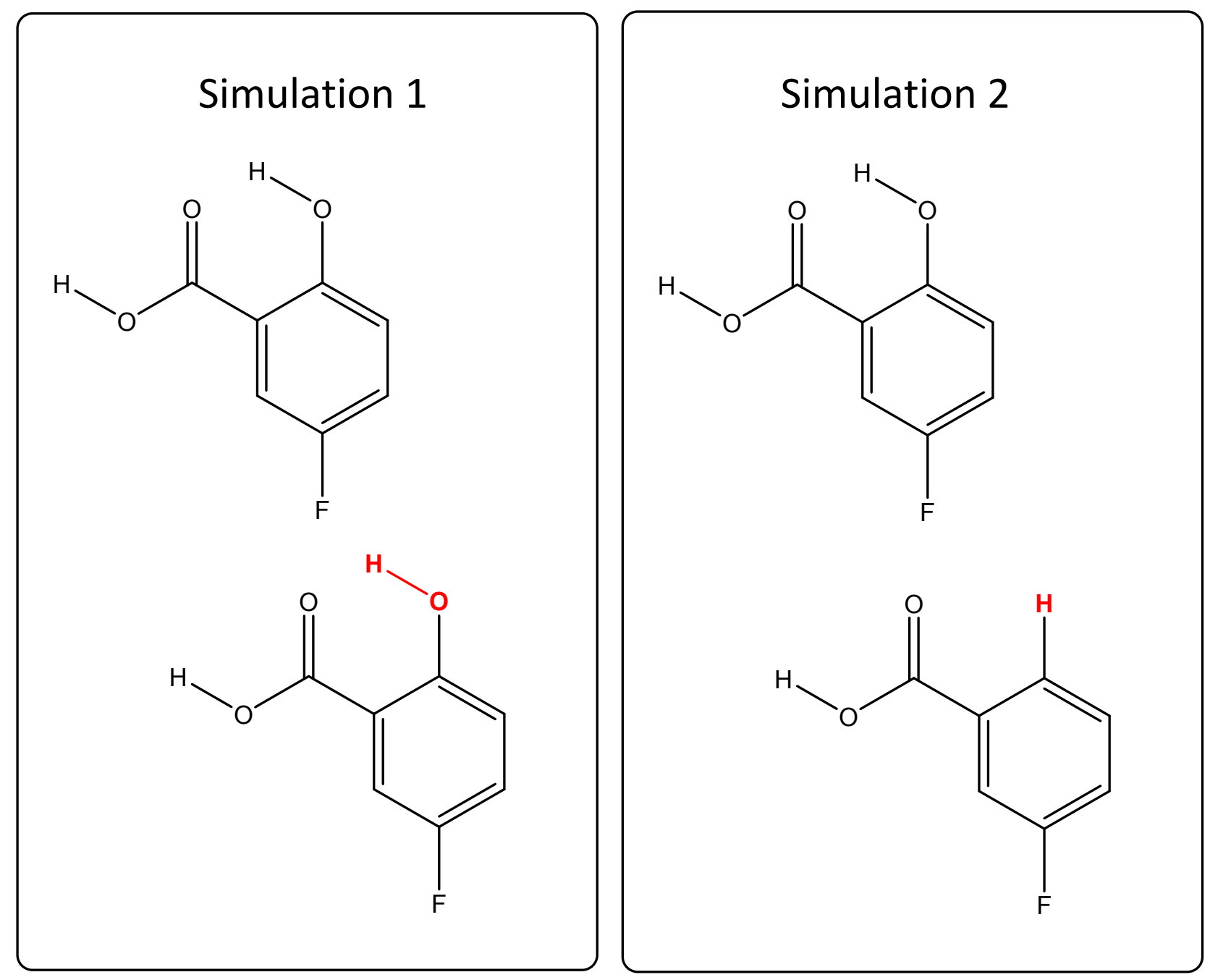

Figure S4.2 Simulation setups for ABENEB. Changes between simulations are shown in red.

Table S4.2. SAPT2+ results for the two simulations (energies in $\mathrm{kcal} / \mathrm{mol}$ ).

\begin{tabular}{lcc} 
& simulation 1 & simulation 2 \\
electrostatics & -0.569 & 0.787 \\
exchange & 2.062 & 1.350 \\
induction & -0.270 & -0.316 \\
dispersion & -2.215 & -1.507 \\
total & -0.992 & 0.314 \\
\hline
\end{tabular}


S5. C-F...N_acc geometry distributions

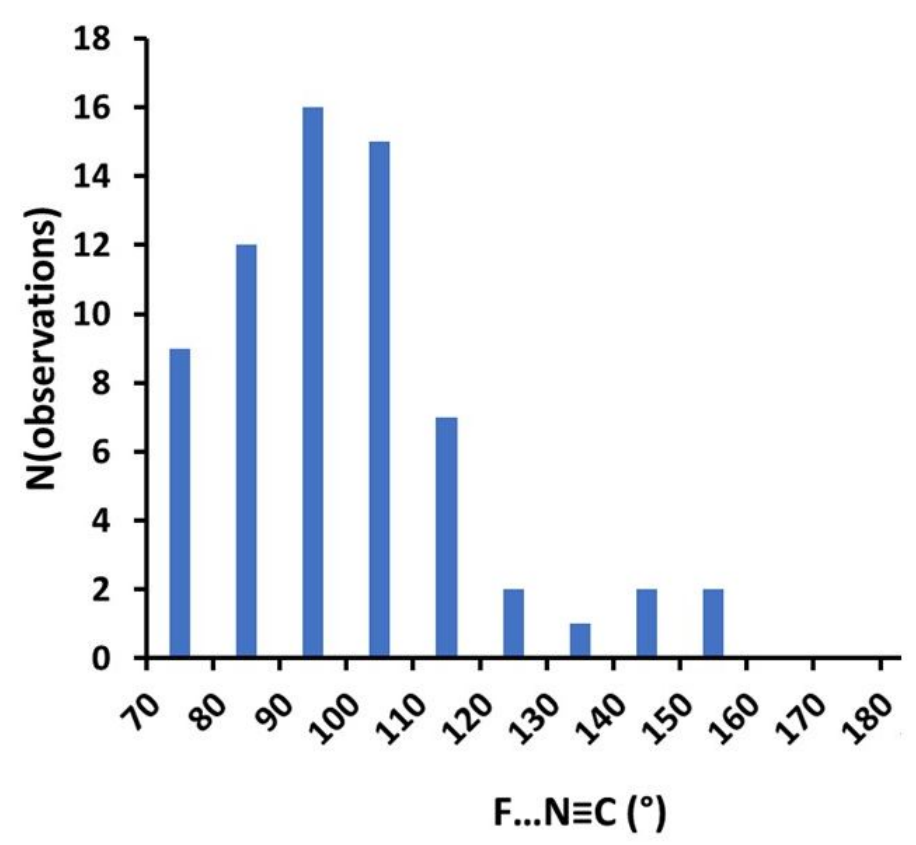

Figure S5.1. Distribution of $\mathrm{F} \ldots \mathrm{N} \equiv \mathrm{C}$ angle in contacts with $\mathrm{F} \ldots \mathrm{N} \leq \operatorname{sum}$ of vdw radii +0.2 $\AA ; \mathrm{C}-\mathrm{F} . . \mathrm{N} \geq 150^{\circ}$.

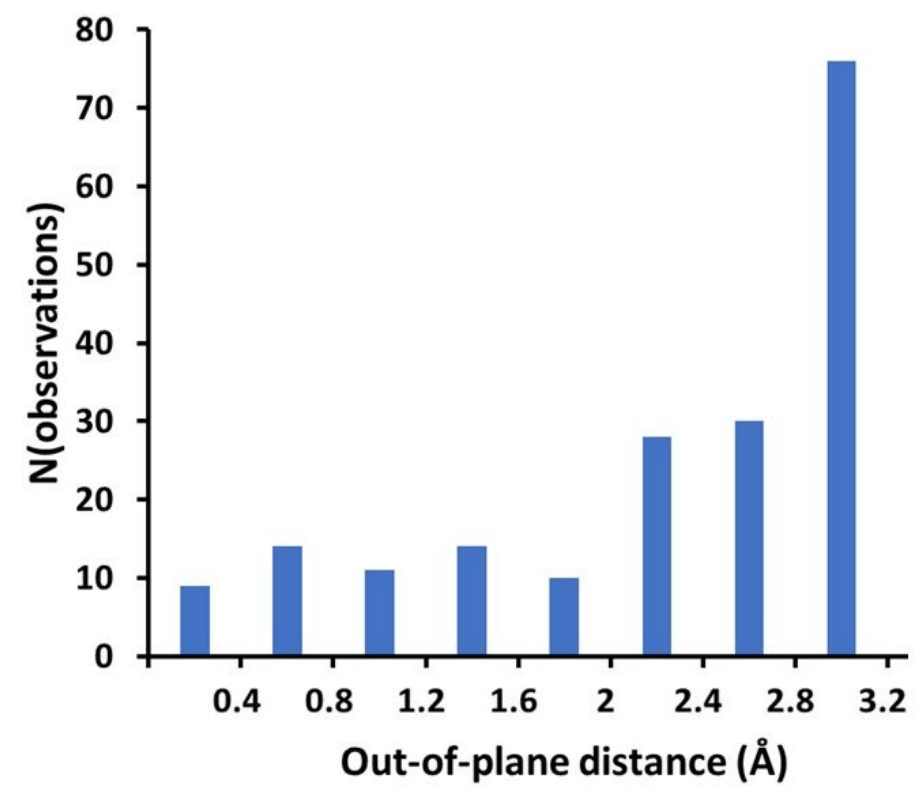

Figure S5.2. Distribution of $F$ distance from $R^{1}-N-R^{2}$ plane in contacts with $F \ldots N \leq$ sum of $\mathrm{vdw}$ radii $+0.2 \AA ; \mathrm{C}-\mathrm{F} \ldots \mathrm{N} \geq 150^{\circ}$ ( $\mathrm{N}$ constrained to be 2 -coordinate). 


\section{S6. $R_{F}$ and $R_{F}^{M}$ tables}

Notes:

- All values are based on the Alvarez van der Waals radii and are for primary, line-ofsight interactions.

- $N=$ number of structures on which $R_{\mathrm{F}}$ estimates based. These were structures containing atoms of both the base and contact atom types. If an angle constraint is applied, structures must also contain base atoms forming primary contacts satisfying the constraint.

- $l q$ and $u q=$ lower and upper quartiles of $R_{\mathrm{F}}$ values, estimated by bootstrapping.

- $R_{\mathrm{F}}{ }^{\mathrm{M}}$ values are given only once for interactions between different atom types. No $R_{\mathrm{F}}{ }^{\mathrm{M}}$ values are given in Table 6.9 because they would correspond to interactions in which the angle constraint applies to both base and contact atoms.

Table S6.1. F...F

\begin{tabular}{|c|c|c|c|c|c|c|}
\hline base atom & contact atom & $N$ & $R_{\mathrm{F}}$ & $l q$ & $u q$ & $R_{\mathrm{F}}^{\mathrm{M}}$ \\
\hline $\mathrm{F}_{-} \mathrm{CF}_{3} \mathrm{sh}$ & $\mathrm{F}_{-} \mathrm{CF}_{3} \mathrm{sh}$ & 6271 & 1.26 & 1.23 & 1.29 & 1.26 \\
\hline $\mathrm{F}_{-} \mathrm{CF}_{3} \mathrm{sh}$ & $\mathrm{F}_{-} \mathrm{CF}_{3} \mathrm{md}$ & 6267 & 1.01 & 0.99 & 1.04 & 0.99 \\
\hline $\mathrm{F}_{-} \mathrm{CF}_{3} \mathrm{md}$ & $\mathrm{F}_{-} \mathrm{CF}_{3} \mathrm{sh}$ & 6267 & 0.96 & 0.94 & 0.98 & \\
\hline $\mathrm{F}_{-} \mathrm{CF}_{3} \mathrm{md}$ & $\mathrm{F}_{-} \mathrm{CF}_{3} \mathrm{md}$ & 6267 & 0.94 & 0.91 & 0.96 & 0.94 \\
\hline $\mathrm{F}_{-} \mathrm{C}_{6} \mathrm{~F}_{5}$ & $\mathrm{~F}_{-} \mathrm{C}_{6} \mathrm{~F}_{5}$ & 710 & 0.88 & 0.87 & 0.89 & 0.88 \\
\hline $\mathrm{F}_{-} \mathrm{CF}_{3} \mathrm{sh}$ & $\mathrm{F}_{-} \mathrm{CF}_{3} \lg$ & 6267 & 0.84 & 0.82 & 0.86 & 0.80 \\
\hline $\mathrm{F}_{-} \mathrm{CF}_{3} \mathrm{md}$ & $\mathrm{F}_{-} \mathrm{CF}_{3} \lg$ & 6267 & 0.78 & 0.76 & 0.80 & 0.77 \\
\hline $\mathrm{F}_{-} \mathrm{CF}_{3} \lg$ & $\mathrm{F}_{-} \mathrm{CF}_{3} \mathrm{sh}$ & 6267 & 0.76 & 0.74 & 0.78 & \\
\hline $\mathrm{F}_{-} \mathrm{CF}_{3} \lg$ & $\mathrm{F}_{-} \mathrm{CF}_{3} \mathrm{md}$ & 6267 & 0.75 & 0.73 & 0.77 & \\
\hline $\mathrm{F}_{-} \mathrm{CF}_{3} \lg$ & $\mathrm{F}_{-} \mathrm{CF}_{3} \lg$ & 6271 & 0.75 & 0.73 & 0.77 & 0.75 \\
\hline F_aro & F_aro & 8084 & 0.67 & 0.66 & 0.68 & 0.67 \\
\hline F_ali & F_ali & 1277 & 0.24 & 0.20 & 0.27 & 0.24 \\
\hline F_phe & F_phe & 1249 & 0.17 & 0.14 & 0.19 & 0.17 \\
\hline $\mathrm{F}_{-} \mathrm{CF}_{3} \mathrm{sh}$ & F_aro & 304 & 1.28 & 1.19 & 1.37 & 1.00 \\
\hline F_aro & $\mathrm{F}_{-} \mathrm{CF}_{3} \mathrm{sh}$ & 304 & 0.78 & 0.70 & 0.86 & \\
\hline
\end{tabular}




\begin{tabular}{|c|c|c|c|c|c|c|}
\hline $\mathrm{F}_{-} \mathrm{CF}_{3} \mathrm{md}$ & F_aro & 304 & 1.06 & 0.98 & 1.14 & 1.13 \\
\hline F_aro & $\mathrm{F}_{-} \mathrm{CF}_{3} \mathrm{md}$ & 304 & 1.20 & 1.10 & 1.29 & \\
\hline $\mathrm{F}_{-} \mathrm{CF}_{3} \lg$ & F_aro & 304 & 0.93 & 0.85 & 1.00 & 0.97 \\
\hline F_aro & $\mathrm{F}_{-} \mathrm{CF}_{3} \lg$ & 304 & 1.02 & 0.93 & 1.10 & \\
\hline F_org & F_org & 20905 & 0.88 & 0.87 & 0.88 & 0.88 \\
\hline
\end{tabular}

Table S6.2. F...F in centrosymmetric structures

\begin{tabular}{|c|c|c|c|c|c|c|}
\hline base atom & contact atom & $N$ & $R_{\mathrm{F}}$ & $l q$ & $u q$ & $R_{\mathrm{F}}^{\mathrm{M}}$ \\
\hline $\mathrm{F}_{-} \mathrm{CF}_{3} \mathrm{sh}$ & $\mathrm{F}_{-} \mathrm{CF}_{3} \mathrm{sh}$ & 4417 & 1.41 & 1.37 & 1.44 & 1.41 \\
\hline $\mathrm{F}_{-} \mathrm{CF}_{3} \mathrm{sh}$ & $\mathrm{F}_{-} \mathrm{CF}_{3} \mathrm{md}$ & 4413 & 1.02 & 0.99 & 1.04 & 0.99 \\
\hline $\mathrm{F}_{-} \mathrm{CF}_{3} \mathrm{md}$ & $\mathrm{F}_{-} \mathrm{CF}_{3} \mathrm{sh}$ & 4413 & 0.96 & 0.93 & 0.98 & \\
\hline $\mathrm{F}_{-} \mathrm{CF}_{3} \mathrm{md}$ & $\mathrm{F}_{-} \mathrm{CF}_{3} \mathrm{md}$ & 4413 & 1.03 & 1.00 & 1.06 & 1.03 \\
\hline $\mathrm{F}_{-} \mathrm{C}_{6} \mathrm{~F}_{5}$ & $\mathrm{~F}_{-} \mathrm{C}_{6} \mathrm{~F}_{5}$ & 583 & 0.91 & 0.89 & 0.92 & 0.91 \\
\hline $\mathrm{F}_{-} \mathrm{CF}_{3} \mathrm{sh}$ & $\mathrm{F}_{-} \mathrm{CF}_{3} \lg$ & 4413 & 0.85 & 0.83 & 0.88 & 0.81 \\
\hline $\mathrm{F}_{-} \mathrm{CF}_{3} \mathrm{md}$ & $\mathrm{F}_{-} \mathrm{CF}_{3} \lg$ & 4413 & 0.78 & 0.76 & 0.80 & 0.76 \\
\hline $\mathrm{F}_{-} \mathrm{CF}_{3} \lg$ & $\mathrm{F}_{-} \mathrm{CF}_{3} \mathrm{sh}$ & 4413 & 0.76 & 0.74 & 0.78 & \\
\hline $\mathrm{F}_{-} \mathrm{CF}_{3} \lg$ & $\mathrm{F}_{-} \mathrm{CF}_{3} \mathrm{md}$ & 4413 & 0.75 & 0.72 & 0.77 & \\
\hline $\mathrm{F}_{-} \mathrm{CF}_{3} \lg$ & $\mathrm{F}_{-} \mathrm{CF}_{3} \lg$ & 4416 & 0.81 & 0.79 & 0.84 & 0.81 \\
\hline F_aro & F_aro & 6410 & 0.68 & 0.67 & 0.70 & 0.68 \\
\hline F_ali & F_ali & 525 & 0.36 & 0.30 & 0.41 & 0.36 \\
\hline F_phe & F_phe & 821 & 0.19 & 0.16 & 0.23 & 0.19 \\
\hline
\end{tabular}

Table S6.3. F...F in noncentrosymmetric structures

$\begin{array}{lllllll}\text { base atom } & \text { contact atom } & N & R_{\mathrm{F}} & l q & u q & R_{\mathrm{F}}{ }^{\mathrm{M}} \\ \mathrm{F} \_\mathrm{CF}_{3} \mathrm{sh} & \mathrm{F}_{-} \mathrm{CF}_{3} \mathrm{sh} & 1854 & 0.75 & 0.70 & 0.80 & 0.75 \\ \mathrm{~F}_{-} \mathrm{CF}_{3} \mathrm{sh} & \mathrm{F}_{-} \mathrm{CF}_{3} \mathrm{md} & 1854 & 1.00 & 0.95 & 1.05 & 0.98 \\ \mathrm{~F}_{-} \mathrm{CF}_{3} \mathrm{md} & \mathrm{F}_{-} \mathrm{CF}_{3} \mathrm{sh} & 1854 & 0.96 & 0.91 & 1.01 & \\ \mathrm{~F}_{-} \mathrm{CF}_{3} \mathrm{md} & \mathrm{F}_{-} \mathrm{CF}_{3} \mathrm{md} & 1854 & 0.61 & 0.57 & 0.65 & 0.61 \\ \mathrm{~F}_{-} \mathrm{C}_{6} \mathrm{~F}_{5} & \mathrm{~F}_{-} \mathrm{C}_{6} \mathrm{~F}_{5} & 127 & 0.76 & 0.72 & 0.79 & 0.76 \\ \mathrm{~F}_{-} \mathrm{CF}_{3} \mathrm{sh} & \mathrm{F}_{-} \mathrm{CF}_{3} \mathrm{lg} & 1854 & 0.79 & 0.74 & 0.83 & 0.77 \\ \mathrm{~F}_{-} \mathrm{CF}_{3} \mathrm{md} & \mathrm{F}_{-} \mathrm{CF}_{3} \mathrm{lg} & 1854 & 0.79 & 0.75 & 0.83 & 0.79 \\ \mathrm{~F}_{-} \mathrm{CF}_{3} \mathrm{lg} & \mathrm{F}_{-} \mathrm{CF}_{3} \mathrm{sh} & 1854 & 0.75 & 0.71 & 0.80 & \end{array}$




\begin{tabular}{lllllll} 
F_CF $31 \mathrm{lg}$ & F_CF $\mathrm{md}$ & 1854 & 0.78 & 0.74 & 0.83 & \\
F_CF $_{3} \mathrm{lg}$ & F_CF$_{3} l \mathrm{lg}$ & 1855 & 0.53 & 0.48 & 0.57 & 0.53 \\
F_aro & F_aro & 1674 & 0.61 & 0.58 & 0.63 & 0.61 \\
F_ali & F_ali & 752 & 0.11 & 0.09 & 0.13 & 0.11 \\
F_phe & F_phe & 428 & 0.10 & 0.07 & 0.14 & 0.10 \\
\hline
\end{tabular}

Table S6.4. F...H_C

\begin{tabular}{|c|c|c|c|c|c|c|}
\hline base atom & contact atom & $N$ & $R_{\mathrm{F}}$ & $l q$ & $u q$ & $R_{\mathrm{F}}^{\mathrm{M}}$ \\
\hline $\mathrm{F}_{-} \mathrm{CF}_{3} \mathrm{sh}$ & H_C & 6122 & 2.01 & 1.99 & 2.02 & 1.63 \\
\hline $\mathrm{F}_{-} \mathrm{CF}_{3} \mathrm{md}$ & H_C & 6118 & 2.20 & 2.19 & 2.21 & 1.83 \\
\hline $\mathrm{F}_{-} \mathrm{C}_{6} \mathrm{~F}_{5}$ & H_C & 659 & 2.34 & 2.31 & 2.37 & 1.96 \\
\hline $\mathrm{F}_{-} \mathrm{CF}_{3} \lg$ & H_C & 6121 & 2.40 & 2.38 & 2.41 & 2.03 \\
\hline F_aro & H_C & 7837 & 2.72 & 2.71 & 2.74 & 2.33 \\
\hline F_ali & H_C & 1255 & 2.26 & 2.24 & 2.28 & 2.09 \\
\hline F_phe & H_C & 1249 & 2.44 & 2.42 & 2.46 & 2.24 \\
\hline H_C & $\mathrm{F}_{-} \mathrm{CF}_{3} \mathrm{sh}$ & 6122 & 1.33 & 1.32 & 1.34 & \\
\hline H_C & $\mathrm{F}_{-} \mathrm{CF}_{3} \mathrm{md}$ & 6118 & 1.52 & 1.51 & 1.52 & \\
\hline H_C & $\mathrm{F}_{-} \mathrm{C}_{6} \mathrm{~F}_{5}$ & 659 & 1.64 & 1.62 & 1.66 & \\
\hline H_C & $\mathrm{F}_{-} \mathrm{CF}_{3} \lg$ & 6121 & 1.72 & 1.71 & 1.73 & \\
\hline H_C & F_aro & 7837 & 1.99 & 1.98 & 2.00 & \\
\hline H_C & F_ali & 1255 & 1.93 & 1.91 & 1.95 & \\
\hline H_C & F_phe & 1249 & 2.06 & 2.03 & 2.08 & \\
\hline
\end{tabular}

Table S6.5. F...H_X

$\begin{array}{lllllll}\text { base atom } & \text { contact atom } & N & R_{\mathrm{F}} & l q & u q & R_{\mathrm{F}}{ }^{\mathrm{M}} \\ \text { F_CF } 3 \text { sh } & \text { H_X } & 3170 & 0.67 & 0.63 & 0.71 & 0.34 \\ \text { F_CF } \mathrm{C} \text { _ } & \text { H_X } & 3169 & 0.79 & 0.74 & 0.83 & 0.44 \\ \text { F_C }_{6} \mathrm{~F}_{5} & \text { H_X } & 279 & 0.39 & 0.33 & 0.45 & 0.34 \\ \text { F_CF } & \text { H_X } & 3171 & 0.80 & 0.75 & 0.84 & 0.50 \\ \text { F_aro } & \text { H_X } & 3728 & 0.93 & 0.90 & 0.97 & 0.66 \\ \text { F_ali } & \text { H_X } & 664 & 1.44 & 1.32 & 1.56 & 0.75 \\ \text { F_phe } & \text { H_X } & 694 & 0.98 & 0.86 & 1.09 & 0.71\end{array}$




\begin{tabular}{llllll} 
H_X & F_CF 3 sh & 3170 & 0.17 & 0.16 & 0.19 \\
H_X & F_CF ${ }_{3}$ md & 3169 & 0.24 & 0.23 & 0.26 \\
H_X & F_C $6 F_{5}$ & 279 & 0.30 & 0.26 & 0.33 \\
H_X & F_CF 19 & 3171 & 0.32 & 0.30 & 0.34 \\
H_X & F_aro & 3728 & 0.47 & 0.45 & 0.48 \\
H_X & F_ali & 664 & 0.39 & 0.34 & 0.44 \\
H_X & F_phe & 694 & 0.52 & 0.46 & 0.57 \\
\hline
\end{tabular}

Table S6.6. F...H_Cpos, F...H_Csp, etc.

\begin{tabular}{|c|c|c|c|c|c|c|}
\hline base atom & contact atom & $N$ & $R_{\mathrm{F}}$ & $l q$ & $u q$ & $R_{\mathrm{F}}^{\mathrm{M}}$ \\
\hline F_org & H_Cpos & 1972 & 1.77 & 1.74 & 1.81 & 1.34 \\
\hline F_org & H_Csp & 100 & 4.81 & 4.39 & 5.24 & 3.45 \\
\hline F_org & H_Cpolar & 3625 & 3.13 & 3.07 & 3.19 & 2.34 \\
\hline F_org & H_Caro & 17146 & 2.81 & 2.80 & 2.82 & 2.28 \\
\hline F_org & H_Csp ${ }^{2}$ & 5257 & 2.60 & 2.56 & 2.64 & 2.15 \\
\hline F_org & H_Csp ${ }^{3}$ & 16144 & 1.92 & 1.91 & 1.92 & 1.72 \\
\hline H_Cpos & F_org & 1972 & 1.02 & 1.00 & 1.04 & \\
\hline H_Csp & F_org & 100 & 2.47 & 2.27 & 2.67 & \\
\hline H_Cpolar & F_org & 3625 & 1.75 & 1.72 & 1.78 & \\
\hline H_Caro & F_org & 17146 & 1.85 & 1.84 & 1.86 & \\
\hline $\mathrm{H}_{-} \mathrm{Csp}^{2}$ & F_org & 5257 & 1.77 & 1.75 & 1.79 & \\
\hline H_Csp ${ }^{3}$ & F_org & 16144 & 1.54 & 1.54 & 1.55 & \\
\hline
\end{tabular}

Table S6.7. O...H_Cpos, O...H_Csp, etc.

\begin{tabular}{|c|c|c|c|c|c|c|}
\hline base atom & contact atom & $N$ & $R_{\mathrm{F}}$ & $l q$ & $u q$ & $R_{\mathrm{F}}{ }^{\mathrm{M}}$ \\
\hline $\mathrm{O}$ & H_Cpos & 1730 & 3.72 & 3.67 & 3.78 & 3.74 \\
\hline $\mathrm{O}$ & H_Csp & 82 & 8.08 & 7.37 & 8.79 & 6.25 \\
\hline $\mathrm{O}$ & H_Cpolar & 2795 & 3.90 & 3.82 & 3.98 & 3.49 \\
\hline $\mathrm{O}$ & H_Caro & 13976 & 2.53 & 2.52 & 2.54 & 2.43 \\
\hline $\mathrm{O}$ & H_Csp ${ }^{2}$ & 4157 & 2.92 & 2.87 & 2.98 & 2.92 \\
\hline $\mathrm{O}$ & H_Csp ${ }^{3}$ & 13978 & 1.64 & 1.63 & 1.65 & 1.73 \\
\hline H_Cpos & $\mathrm{O}$ & 1730 & 3.75 & 3.72 & 3.79 & \\
\hline
\end{tabular}




\begin{tabular}{llllll} 
H_Csp & $\mathrm{O}$ & 82 & 4.83 & 4.47 & 5.22 \\
H_Cpolar & $\mathrm{O}$ & 2795 & 3.12 & 3.08 & 3.17 \\
H_Caro & $\mathrm{O}$ & 13976 & 2.34 & 2.33 & 2.35 \\
H_Csp $^{2}$ & $\mathrm{O}$ & 4157 & 2.91 & 2.88 & 2.95 \\
H_Csp $^{3}$ & $\mathrm{O}$ & 13978 & 1.82 & 1.82 & 1.83 \\
\hline
\end{tabular}

Table S6.8. F...Hal (Hal $=$ heavier halogen $)$

\begin{tabular}{lllllll} 
base atom & contact atom & $N$ & $R_{\mathrm{F}}$ & $l q$ & $u q$ & $R_{\mathrm{F}}{ }^{\mathrm{M}}$ \\
F_org & Cl_ali & 639 & 0.95 & 0.91 & 0.98 & 0.97 \\
F_org & Cl_aro & 1295 & 1.01 & 0.98 & 1.05 & 1.01 \\
F_org & Br_org & 1326 & 0.74 & 0.72 & 0.77 & 0.83 \\
F_org & I_org & 1202 & 0.38 & 0.37 & 0.40 & 0.33 \\
Cl_ali & F_org & 639 & 0.98 & 0.93 & 1.03 & \\
Cl_aro & F_org & 1295 & 1.01 & 0.97 & 1.06 & \\
Br_org & F_org & 1326 & 0.93 & 0.89 & 0.98 & \\
I_org & F_org & 1202 & 0.29 & 0.27 & 0.31 & \\
\hline
\end{tabular}

Table S6.9. F...Hal with $\mathrm{C}-<$ base atom $>\ldots<$ contact atom $>$ angle $\geq 150^{\circ}$

\begin{tabular}{llllll} 
base atom & contact atom & $N$ & $R_{\mathrm{F}}$ & $l q$ & $u q$ \\
F_org & Cl_ali & 342 & 1.13 & 1.06 & 1.20 \\
F_org & Cl_aro & 527 & 1.10 & 1.02 & 1.18 \\
F_org & Br_org & 655 & 0.77 & 0.71 & 0.82 \\
F_org & I_org & 750 & 0.34 & 0.32 & 0.37 \\
Cl_ali & F_org & 293 & 1.71 & 1.60 & 1.82 \\
Cl_aro & F_org & 494 & 1.91 & 1.80 & 2.02 \\
Br_org & F_org & 691 & 1.34 & 1.26 & 1.42 \\
I_org & F_org & 1073 & 0.25 & 0.22 & 0.27 \\
\hline
\end{tabular}

Table S6.10. F...O

$\begin{array}{lllllll}\text { base atom } & \text { contact atom } & N & R_{\mathrm{F}} & l q & u q & R_{\mathrm{F}}{ }^{\mathrm{M}} \\ \mathrm{F}_{-} \mathrm{CF}_{3} \mathrm{sh} & \mathrm{O} & 5195 & 0.30 & 0.29 & 0.31 & 0.30\end{array}$




\begin{tabular}{|c|c|c|c|c|c|c|}
\hline $\mathrm{F}_{-} \mathrm{CF}_{3} \mathrm{md}$ & $\mathrm{O}$ & 5193 & 0.23 & 0.22 & 0.24 & 0.24 \\
\hline $\mathrm{F} \_\mathrm{C}_{6} \mathrm{~F}_{5}$ & $\mathrm{O}$ & 402 & 0.30 & 0.28 & 0.33 & 0.30 \\
\hline $\mathrm{F}_{-} \mathrm{CF}_{3} \lg$ & $\mathrm{O}$ & 5195 & 0.20 & 0.19 & 0.21 & 0.24 \\
\hline F_aro & $\mathrm{O}$ & 5914 & 0.16 & 0.15 & 0.17 & 0.18 \\
\hline F_ali & $\mathrm{O}$ & 1161 & 0.07 & 0.06 & 0.08 & 0.10 \\
\hline F_phe & $\mathrm{O}$ & 1105 & 0.04 & 0.03 & 0.06 & 0.10 \\
\hline $\mathrm{O}$ & $\mathrm{F}_{-} \mathrm{CF}_{3} \mathrm{sh}$ & 5195 & 0.31 & 0.29 & 0.32 & \\
\hline $\mathrm{O}$ & $\mathrm{F}_{-} \mathrm{CF}_{3} \mathrm{md}$ & 5193 & 0.25 & 0.24 & 0.26 & \\
\hline $\mathrm{O}$ & $\mathrm{F}_{-} \mathrm{C}_{6} \mathrm{~F}_{5}$ & 402 & 0.31 & 0.29 & 0.33 & \\
\hline $\mathrm{O}$ & $\mathrm{F}_{-} \mathrm{CF}_{3} \lg$ & 5195 & 0.28 & 0.26 & 0.29 & \\
\hline $\mathrm{O}$ & F_aro & 5914 & 0.21 & 0.20 & 0.21 & \\
\hline $\mathrm{O}$ & F_ali & 1161 & 0.14 & 0.13 & 0.16 & \\
\hline $\mathrm{O}$ & F_phe & 1105 & 0.22 & 0.20 & 0.25 & \\
\hline
\end{tabular}

Table S6.11. F...O with C-F...O angle $\geq 150^{\circ}$

\begin{tabular}{llllll} 
base atom & contact atom & $N$ & $R_{\mathrm{F}}$ & $l q$ & $u q$ \\
F_CF $_{3} \mathrm{sh}$ & $\mathrm{O}$ & 1770 & 0.27 & 0.25 & 0.30 \\
F_CF $_{3} \mathrm{md}$ & $\mathrm{O}$ & 1507 & 0.20 & 0.18 & 0.22 \\
F_C $_{6} \mathrm{~F}_{5}$ & $\mathrm{O}$ & 331 & 0.22 & 0.17 & 0.26 \\
F_CF $_{3} \mathrm{lg}$ & $\mathrm{O}$ & 1270 & 0.23 & 0.20 & 0.25 \\
F_aro & $\mathrm{O}$ & 2177 & 0.18 & 0.16 & 0.20 \\
F_ali & $\mathrm{O}$ & 325 & 0.07 & 0.04 & 0.09 \\
F_phe & $\mathrm{O}$ & 271 & 0.08 & 0.04 & 0.12 \\
\hline
\end{tabular}

Table S6.12. F...N_acc

$\begin{array}{lllllll}\text { base atom } & \text { contact atom } & N & R_{\mathrm{F}} & l q & u q & R_{\mathrm{F}}{ }^{\mathrm{M}} \\ \text { F_CF } 3 \text { sh } & \text { N_acc } & 2624 & 0.35 & 0.32 & 0.38 & 0.31 \\ \text { F_CF }_{3} \mathrm{md} & \text { N_acc } & 2621 & 0.32 & 0.30 & 0.34 & 0.28 \\ \text { F_C }_{6} \mathrm{~F}_{5} & \text { N_acc } & 273 & 0.40 & 0.35 & 0.44 & 0.41 \\ \text { F_CF}_{3} l g & \text { N_acc } & 2623 & 0.30 & 0.28 & 0.33 & 0.29 \\ \text { F_aro } & \text { N_acc } & 3941 & 0.21 & 0.20 & 0.23 & 0.22 \\ \text { F_ali } & \text { N_acc } & 262 & 0.19 & 0.10 & 0.25 & 0.18\end{array}$




\begin{tabular}{lllllll} 
F_phe & N_acc & 538 & 0.22 & 0.16 & 0.28 & 0.33 \\
N_acc & F_CF 3 sh & 2624 & 0.27 & 0.25 & 0.29 & \\
N_acc & F_CF 3 md & 2621 & 0.25 & 0.23 & 0.27 & \\
N_acc & F_C $F_{5}$ & 273 & 0.42 & 0.37 & 0.46 & \\
N_acc & F_CF 19 & 2623 & 0.27 & 0.25 & 0.30 & \\
N_acc & F_aro & 3941 & 0.22 & 0.21 & 0.23 \\
N_acc & F_ali & 262 & 0.17 & 0.12 & 0.22 \\
N_acc & F_phe & 538 & 0.49 & 0.41 & 0.56 \\
\hline
\end{tabular}

Table S6.13. F...C_sp ${ }^{3}$

\begin{tabular}{|c|c|c|c|c|c|c|}
\hline base atom & contact atom & $N$ & $R_{\mathrm{F}}$ & $l q$ & $u q$ & $R_{\mathrm{F}}{ }^{\mathrm{M}}$ \\
\hline $\mathrm{F}_{-} \mathrm{CF}_{3} \mathrm{sh}$ & C_sp $\mathrm{sp}^{3}$ & 6271 & 0.56 & 0.54 & 0.57 & 0.84 \\
\hline $\mathrm{F}_{-} \mathrm{CF}_{3} \mathrm{md}$ & C_sp $\mathrm{sp}^{3}$ & 6267 & 0.56 & 0.54 & 0.58 & 0.86 \\
\hline $\mathrm{F}_{-} \mathrm{C}_{6} \mathrm{~F}_{5}$ & $\mathrm{C}_{-} \mathrm{sp}^{3}$ & 480 & 0.69 & 0.66 & 0.73 & 0.98 \\
\hline $\mathrm{F}_{-} \mathrm{CF}_{3} \lg$ & C_sp ${ }^{3}$ & 6271 & 0.50 & 0.49 & 0.52 & 0.83 \\
\hline F_aro & $\mathrm{C}_{-} \mathrm{sp}^{3}$ & 5671 & 0.68 & 0.67 & 0.70 & 1.03 \\
\hline F_ali & $\mathrm{C}_{-} \mathrm{sp}^{3}$ & 1277 & 0.41 & 0.38 & 0.44 & 0.77 \\
\hline F_phe & C_sp ${ }^{3}$ & 1248 & 0.49 & 0.45 & 0.53 & 0.88 \\
\hline C_s $\mathrm{sp}^{3}$ & $\mathrm{~F}_{-} \mathrm{CF}_{3} \mathrm{sh}$ & 6271 & 1.27 & 1.25 & 1.28 & \\
\hline C_sp $\mathrm{sp}^{3}$ & $\mathrm{~F}_{-} \mathrm{CF}_{3} \mathrm{md}$ & 6267 & 1.31 & 1.29 & 1.32 & \\
\hline C_s $\mathrm{sp}^{3}$ & $\mathrm{~F}_{-} \mathrm{C}_{6} \mathrm{~F}_{5}$ & 480 & 1.39 & 1.35 & 1.42 & \\
\hline $\mathrm{C}_{-} \mathrm{sp}^{3}$ & $\mathrm{~F}_{-} \mathrm{CF}_{3} \lg$ & 6271 & 1.36 & 1.35 & 1.38 & \\
\hline C_s $\mathrm{sp}^{3}$ & F_aro & 5671 & 1.56 & 1.54 & 1.57 & \\
\hline C_sp $\mathrm{sp}^{3}$ & F_ali & 1277 & 1.46 & 1.42 & 1.49 & \\
\hline C_sp $\mathrm{sp}^{3}$ & F_phe & 1248 & 1.56 & 1.51 & 1.61 & \\
\hline
\end{tabular}

Table S6.14. F...C_ar

$\begin{array}{lllllll}\text { base atom } & \text { contact atom } & N & R_{\mathrm{F}} & l q & u q & R_{\mathrm{F}}{ }^{\mathrm{M}} \\ \mathrm{F}_{-} \mathrm{CF}_{3} \mathrm{sh} & \text { C_aro } & 5274 & 0.51 & 0.50 & 0.52 & 0.58 \\ \mathrm{~F}_{-} \mathrm{CF}_{3} \mathrm{md} & \text { C_aro } & 5271 & 0.48 & 0.47 & 0.49 & 0.59 \\ \mathrm{~F}_{-} \mathrm{C}_{6} \mathrm{~F}_{5} & \text { C_aro } & 710 & 0.79 & 0.77 & 0.81 & 0.91 \\ \mathrm{~F}_{-} \mathrm{CF}_{3} 1 \mathrm{lg} & \text { C_aro } & 5272 & 0.41 & 0.40 & 0.42 & 0.52\end{array}$




\begin{tabular}{lllllll} 
F_aro & C_aro & 8084 & 0.47 & 0.46 & 0.48 & 0.59 \\
F_ali & C_aro & 877 & 0.24 & 0.22 & 0.26 & 0.36 \\
F_phe & C_aro & 1249 & 0.23 & 0.22 & 0.24 & 0.41 \\
C_aro & F_CF 3 sh & 5274 & 0.66 & 0.65 & 0.67 & \\
C_aro & F_CF 3 md & 5271 & 0.73 & 0.72 & 0.74 & \\
C_aro & F_C $\mathrm{C}_{5}$ & 710 & 1.05 & 1.03 & 1.07 & \\
C_aro & F_CF & 5272 & 0.66 & 0.65 & 0.67 & \\
C_aro & F_aro & 8084 & 0.73 & 0.72 & 0.74 & \\
C_aro & F_ali & 877 & 0.56 & 0.53 & 0.59 & \\
C_aro & F_phe & 1249 & 0.72 & 0.70 & 0.75 & \\
\hline
\end{tabular}

Table S6.15. F...C_aro_CH, F_C_aro_N, etc.

\begin{tabular}{lllllll} 
base atom & contact atom & $N$ & $R_{\mathrm{F}}$ & $l q$ & $u q$ & $R_{\mathrm{F}}{ }^{\mathrm{M}}$ \\
F_org & C_aro_CH & 2898 & 0.33 & 0.32 & 0.34 & 0.44 \\
F_org & C_aro_N & 2079 & 0.53 & 0.51 & 0.55 & 0.63 \\
F_org & C_aro_N 2 & 570 & 0.77 & 0.73 & 0.82 & 0.76 \\
F_org & C_aro_F & 2434 & 0.97 & 0.96 & 0.99 & 1.02 \\
F_org & C_aro_N & 524 & 0.95 & 0.91 & 0.99 & 1.01 \\
C_aro_CH & F_org & 2898 & 0.59 & 0.58 & 0.60 & \\
C_aro_N & F_org & 2079 & 0.75 & 0.73 & 0.77 & \\
C_aro_N & F_org & 570 & 0.75 & 0.71 & 0.79 & \\
C_aro_F & F_org & 2434 & 1.06 & 1.05 & 1.07 & \\
C_aro_N & F_org & 524 & 1.08 & 1.04 & 1.12 & \\
\hline
\end{tabular}

Table S6.16. F...C_carbonyl

$\begin{array}{lllllll}\text { base atom } & \text { contact atom } & N & R_{\mathrm{F}} & l q & u q & R_{\mathrm{F}}{ }^{\mathrm{M}} \\ \text { F_CF } \mathrm{CF}_{3} \mathrm{sh} & \text { C_carbonyl } & 3651 & 0.64 & 0.60 & 0.68 & 0.73 \\ \mathrm{~F}_{-} \mathrm{CF}_{3} \mathrm{md} & \text { C_carbonyl } & 3649 & 0.67 & 0.63 & 0.72 & 0.78 \\ \mathrm{~F}_{-} \mathrm{C}_{6} \mathrm{~F}_{5} & \text { C_carbonyl } & 247 & 0.92 & 0.82 & 1.02 & 1.07 \\ \text { F_CF}_{3} \mathrm{lg} & \text { C_carbonyl } & 3651 & 0.84 & 0.79 & 0.89 & 0.95 \\ \text { F_aro } & \text { C_carbonyl } & 3970 & 0.87 & 0.83 & 0.91 & 0.99 \\ \text { F_ali } & \text { C_carbonyl } & 837 & 0.93 & 0.83 & 1.02 & 1.16\end{array}$




$\begin{array}{lllllll}\text { F_phe } & \text { C_carbonyl } & 763 & 0.80 & 0.69 & 0.91 & 1.06 \\ \text { C_carbonyl } & \text { F_CF }_{3} \text { sh } & 3651 & 0.82 & 0.79 & 0.85 & \\ \text { C_carbonyl } & \text { F_CF }_{3} \text { md } & 3649 & 0.91 & 0.87 & 0.95 & \\ \text { C_carbonyl } & \text { F_C }_{6} F_{5} & 247 & 1.23 & 1.16 & 1.30 & \\ \text { C_carbonyl } & \text { F_CF } & & & \\ \text { C_g } & 3651 & 1.06 & 1.03 & 1.10 & \\ \text { C_carbonyl } & \text { F_aro } & 3970 & 1.13 & 1.09 & 1.16 \\ \text { C_carbonyl } & \text { F_ali } & 837 & 1.45 & 1.36 & 1.54 \\ \text { C_carbonyl } & \text { F_phe } & 763 & 1.40 & 1.29 & 1.50\end{array}$

Table S6.17. F...S

\begin{tabular}{lllllll} 
base atom & contact atom & $N$ & $R_{\mathrm{F}}$ & $l q$ & $u q$ & $R_{\mathrm{F}}{ }^{\mathrm{M}}$ \\
F_org & S_R 2 polar & 699 & 0.92 & 0.87 & 0.96 & 0.70 \\
F_org & S_R & 1512 & 0.75 & 0.72 & 0.77 & 0.68 \\
F_org & S_term & 504 & 0.19 & 0.17 & 0.21 & 0.11 \\
S_R2polar & F_org & 699 & 0.53 & 0.48 & 0.57 & \\
S_R2 & F_org & 1512 & 0.61 & 0.59 & 0.64 & \\
S_term & F_org & 504 & 0.06 & 0.04 & 0.08 & \\
\hline
\end{tabular}




\section{REFERENCES}

(1) Varadwaj, A.; Marques, H. M.; Varadwaj, P. R. Nature of Halogen-Centered Intermolecular Interactions in Crystal Growth and Design: Fluorine-Centered Interactions in Dimers in Crystalline Hexafluoropropylene as a Prototype. J. Comput. Chem. 2019, 40, 1836-1860.

(2) Janjić, G. V.; Jelić, S. T.; Trišović, N. P.; Popović, D. M.; Dordević, I. S.; Milčić, M. K. New Theoretical Insight into Fluorination and Fluorine-Fluorine Interactions as a Driving Force in Crystal Structures. Cryst. Growth Des. 2020, 20, 2943-2951.

(3) Esterhuysen, C.; Heßelmann, A.; Clark, T. Trifluoromethyl: An Amphiphilic Noncovalent Bonding Partner. ChemPhysChem 2017, 18, 772-784.

(4) Kroon, J.; Kanters, J. A. Non-Linearity of Hydrogen Bonds in Molecular Crystals. Nature 1974, 248, 667-669.

(5) Parker, T. M.; Burns, L. A.; Parrish, R. M.; Ryno, A. G.; Sherrill, C. D. Levels of Symmetry Adapted Perturbation Theory (SAPT). I. Efficiency and Performance for Interaction Energies. J. Chem. Phys. 2014, 140, 094106. 